\title{
Foot and Ankle Injuries and Treatment
}

Editors

ANISH R. KADAKIA

JOSEPH S. PARK

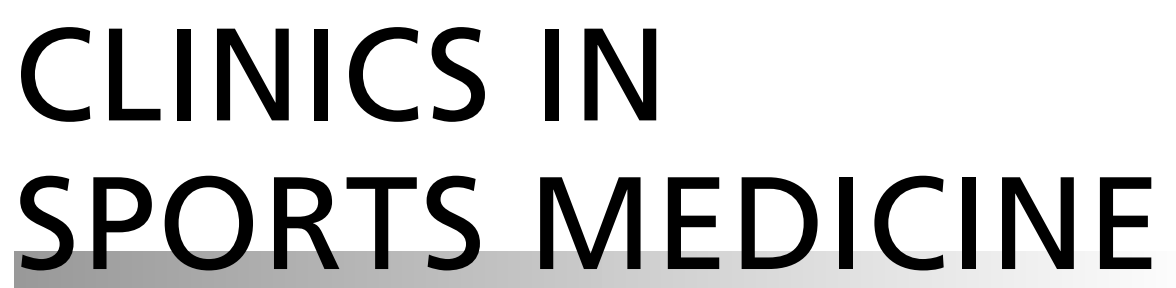

www.sportsmed.theclinics.com

Consulting Editor

MARK D. MILLER

October 2020 • Volume $39 \bullet$ Number 4 